\title{
Judicial Review of EU Acts Affecting Criminal Proceedings
}

\author{
Pascal Schonard ${ }^{\star}$
}

\begin{abstract}
The article analyses the legal state-of-play concerning the right of access to court against EU measures which are relevant for national criminal proceedings (e.g. forwarding of information to national prosecutors by EU bodies). This analysis covers remedies at national, EU and ECHR level. The author suggests that the new wording of the EU Treaties, in particular Article 263(4) of the Treaty on the Functioning of the European Union and Article 47 of the Charter of Fundamental Rights, ensures the individual's right to access the General Court of the EU by codifying relevant ECJ jurisprudence. Indeed, the ECJ had already set out principles and definitions regarding effective judicial review in the past which - if read and applied with care to cases concerning EU acts affecting criminal proceedings - appropriately respond to the new Treaty framework.
\end{abstract}

\section{Introduction}

As the EU is further developing its criminal law dimension, the inner consistency of the EU Area of Freedom, Security and Justice has to face a test: How to reconcile the necessity to guarantee individual freedom and the legitimate quest to meet the challenges of transnational criminality? Of course this question is far from new in legal history, but its growing importance at EU level mirrors the new chapter being opened there. Among the characteristics of this new chapter of EU law are rightssensitive EU competences, in particular in criminal law ${ }^{1}$, on one hand, and, on the other hand, the developing constitutionalism ${ }^{2}$ of and within the EU institutions, underpinned not only by the new requirements of the Lisbon Treaty ${ }^{3}$ but also by deepened institutional awareness of fundamental rights ${ }^{4}$.

\footnotetext{
* Assessor Juris, maître en droit (Paris 1 Panthéon-Sorbonne), Master en administration publique (ÉNA); Administrator at the European Commission, Directorate-General for Justice, Criminal law unit. The views expressed here are solely those of the author in his personal capacity and do not necessarily reflect those of the European Commission.

${ }^{1}$ See in particular Art. 82, 83, 85, 86 and 325 of the Treaty on the Functioning of the EU ("TFEU"); see also the address of Vice-President Reding of 20 January 2011 to the Maastricht University Conference on substantive EU law, "Strengthening justice through criminal law", SPEECH/11/44, http://ec.europa.eu/commission_2010-2014/reding/multimedia/speeches/index_en.htm: "...an intrusive set of rules". Recently, EU legislative action in this field has gained momentum: see, e. g., Directive 2008/99/EC on the protection of the environment through criminal law, OJ L 328, 6. 12. 2008, p. 28; Directive 2005/35/EC on ship-source pollution, OJ L 255, 30. 9. 2005, p. 11, as amended by Directive 2009/123/EC, OJ L 280, 27. 10. 2009, p. 52; Directive 2011/36/EU on preventing and combating trafficking in human beings, OJ L 101, 15. 4. 2011, p. 1; Commission proposal of 29 March 2010 for a directive on combating the sexual abuse, sexual exploitation of children and child pornography, repealing Framework Decision 2004/68/JHA, COM(2010)94 final.

${ }^{2}$ This term is used here to designate a rights-oriented institutional dynamic, not to imply that the current EU treaties have any constitutional character in the strict sense.

${ }^{3}$ Binding force of the Charter of Fundamental Rights, see Art. 6(1) of the Treaty on European Union ("TEU"); obligation of the EU to accede to the European Convention for the Protection of Human Rights and Fundamental Freedoms, Art. 6(2) TEU.

${ }^{4}$ See, e. g., the Fundamental Rights 'checklist' in the Staff Working Document accompanying the Commission's 2010 Report on the Application of the EU Charter of Fundamental Rights, SEC(2011)396 final; or the Commission
} 
Key to this debate is the question of judicial review - understood here in the sense of a right of individuals to seek the decision of a tribunal -, which forms the concrete nexus between fundamental rights protection and criminal law investigations or proceedings. Access to an effective remedy before a tribunal is enshrined as the first right in the justice chapter of the EU Charter of Fundamental Rights (Art. 47(1)), and - since it draws the procedural conclusions from the Union being based on the rule of law ${ }^{5}$ - could be termed its core provision.

As is well-known, of course, no supranational EU criminal law with direct effect $^{6}$, no European public prosecutor's office and no EU criminal tribunal exist as of now, even though some legal bases in the Treaty on the Functioning of the European Union ("TFEU") may allow for a change in this in the future ${ }^{7}$. Today, criminal investigations and proceedings still take place at national level.

Nonetheless, strengthened tools for providing administrative or criminal investigative contributions have evolved at EU level, which undoubtedly have at least de facto consequences for national criminal proceedings. This is even their very purpose; if they did not have such effects, their raison d'être would be more than questionable.

It therefore appears pertinent for this article to analyse means and competences of judicial review for acts of EU bodies, to the extent that they have an impact on the commencement of, and/or further proceedings in, a criminal investigation or trial, including as regards jurisdiction, provisional measures, evidence-taking and judgment. Examples of such EU acts affecting criminal proceedings would be the forwarding of information by OLAF to national authorities ${ }^{8}$, the requests by Eurojust to conduct an investigation ${ }^{9}$ or similar requests by Europol ${ }^{10}$.

Staff Working Document on Operational guidance on taking account of Fundamental Rights in Commission Impact Assessments, SEC(2011)567 final; also the speech of Vice-President Viviane Reding of 17 September 2010 at the German Institute of Human Rights, "The significance of the EU Charter of Fundamental Rights for European lawmaking", SPEECH/10/463, http://ec.europa.eu/commission_2010-2014/reding/multimedia/speeches/index_en.htm.

${ }^{5}$ See the Explanations relating to the EU Charter of Fundamental Rights, OJ C 303, 14. 12. 2007, p. 2 at 30.

${ }^{6}$ See Ambos, Internationales Strafrecht, Second edition, , 2008, \$11 para. 4, pp. 415-6; Hecker, Europäisches Strafrecht, Second Edition, Berlin, 2007, §4, no. 73, p. 148; Klip, European criminal law, Antwerp, 2009, p. 1. For a compelling rebuttal of the suggestion that Art. 30 of the ECJ Statute might be an exception, see Satzger, Internationales und Europäisches Strafrecht, Second Edition, Munich, 2007, §8 paras 14-15.

${ }^{7}$ See Art. 86, 325(4) TFEU.

${ }^{8}$ Article 10(2) of Regulation (EC) No 1073/1999 of the European Parliament and of the Council of 25 May 1999 concerning investigations conducted by the European Anti-Fraud Office (OLAF), OJ L 136, 31. 5. 1999, p. 1.

${ }^{9}$ Article 7(1)(a)(i) of Council Decision 2002/187/JHA of 28 February 2002 setting up Eurojust with a view to reinforcing the fight against serious crime as amended by Council Decision 2003/659/JHA and by Council Decision 2009/426/JHA of 16 December 2008 on the strengthening of Eurojust.

${ }^{10}$ Article 5(1)(d) of Council Decision 2009/371/JHA of 6 April 2009 setting up the European Police Office (Europol). Not directly relevant in this context are Article 11c(3)(a) of Council Regulation (EC) No 2007/2004 of 26 October 2004 establishing a European Agency for the Management of Operational Cooperation at the External Borders of the Member States of the European Union, OJ L 349, 25. 11. 2004, p. 1, as last amended by Regulation (EU) No 1168/2001 of the European Parliament and of the Council of 25 October 2011, OJ L 304, 22. 11. 2011, p. 1, which merely allows transfer of information to Union law enforcement bodies; or the meta data on asylum procedures of the Member States collected and processed under Article 11 of Regulation (EU) No 439/2010 of the European Parliament and of the Council establishing a European Asylum Support Office, OJ L 132, 29. 5. 2010, p. 11. 


\section{Competent court at national level?}

The Treaties exclude, in principle, a direct review of the compliance of acts of EU bodies with EU law by national courts. ${ }^{11}$ This is implicit in the review procedures foreseen regarding acts of the Union, and in particular the ECJ's competence to issue preliminary rulings, which is designed to ensure uniformity of application of EU law across the Union ${ }^{12}$. This state of affairs is confirmed by the exclusion of national courts' jurisdiction over EU bodies as a matter of their immunities under Article 343 TFEU. ${ }^{13}$ However, some avenues for review at national court level may arise indirectly.

First, it is possible under, and within the limits of, national procedural law to challenge the admissibility of evidence and the lawfulness of other relevant procedural components ${ }^{14}$. National procedural law might thus deny recognition to an EU act for the purposes of ongoing criminal proceedings. While such denial does not formally annul or declare inexistent the EU act, the result is the same: it will not have any legal effects in the relevant forum. Yet such avenues do not necessarily exist under all national laws, and sometimes they are limited to a relatively ${ }^{15}$ toothless declaratory decision on the unlawfulness of the evidence-gathering ${ }^{16}$, which does not necessarily render the use of such evidence unlawful. ${ }^{17}$ Moreover, the national judge may be able to rely on evidence newly and separately gathered after "inspiration" by (EU) information, even if the latter itself was found to be inadmissible as evidence $^{18}$.

Secondly, there might be a possibility to claim damages from the for the wrong application of EU law, if consequences drawn from an EU act or omission were in

${ }^{11}$ ECJ, Case 314/85, Foto Frost v. Hauptzollamt Lübeck-Ost, 1987 ECR p. 4199 at para. 15. This is not called into doubt by the Factortame (I) jurisprudence of the ECJ, because there, only interim results can be upheld by the national court "against" an EU act by reference to a preliminary assessment of (higher ranking) EU law, and may only be subject to simultaneous submission for preliminary ruling on the main proceedings to the ECJ. This in itself is in fact a way of helping the ECJ to better enforce EU law, as national courts act as their functional deputies in such proceedings, see ECJ, Case C-213/89, The Queen v. Secretary of State for Transport ex parte Factortame Ltd, 1990 ECR I2433 at paras $21-2$.

12 Foto Frost, ibid.

${ }^{13}$ See Article 1, second sentence, of Protocol (No 36) on the privileges and immunities of the European Communities of 8 April 1965, OJ C 321E, 29. 12. 2006, p. 318.

${ }^{14}$ See, e. g., $§ 98(2)$, second sentence, and $\S 304$ of the German Code of criminal procedure (StrafprozessordnungStPO), as well as $\S \S 23$ et seq. of the introductory statute to the German law on judicial organisation (Einleitungsgesetz zum Gerichtsverfassungsgesetz - EGGVG).

${ }^{15}$ The mistake in evidence-gathering may lead to a prohibition to use in the case of disproportion between the intrusion into the rights of the defendant and the (lacking) gravity of the accusation at hand, or in case of deliberate and arbitrary circumvention of an essential evidence-taking rule such as judicial competence, Bundesverfassungsgericht, BverfG, 2 BvR 1596/10, Order of 24 February 2011, at para. 10; Bundesgerichtshof, BGH, 3 StR 181/98, Judgment of 11 November 1998, BGHSt 44, p. 243 at 249.

${ }^{16}$ See e. g. Bundesverfassungsgericht, BVerfG, 1 BvR 3229/06, Order of 16 November 2009 at para. 1; for a critical analysis of German jurisprudence on the (secondary) judicial review mechanisms for cases of unlawful investigative acts in criminal proceedings, see Glaser, Der Rechtsschutz nach $§ 98$ Abs. 2 Satz 2 StPO, Tübingen 2008, in particular pp. 82-3.

${ }^{17}$ See Bundesverfassungsgericht, BVerfG, 2 BvR 1596/10, Order of 24 February 2011, at para. 10; Bundesgerichtshof, BGH, 3 StR 181/98, Judgment of 11 November 1998, BGHSt 44, 243 at para. 11.

${ }_{18}$ The 'fruit of the poisonous tree doctrine', developed by the U.S. Supreme Court in the case Silverthorne Lumber Co.v. United States, docket \# 19-358, 251 U.S. 385 (1920), does not apply in at least some EU jurisdictions (e.g. Germany, Sweden). 
breach of EU law, such as data protection rules. ${ }^{19}$ In such proceedings, damages might, however, be denied, simply because EU law does not necessarily provide for a specific consequential decision (thus making the national decision lawful even if the EU act was not), because the national court would implicitly have to rule over the lawfulness of the EU law as such ${ }^{20}$, or because the breach of EU law was not sufficiently manifest in character ${ }^{21}$.

However, as there is nothing in the foregoing remedies which would allow the EU act or omission as such to be challenged ('primary legal remedy'), one might wonder whether the right to an effective remedy under Article 47(1) of the EU Charter of Fundamental Rights (the "Charter") could possibly be complied with through any of these avenues in national courts - even where they do exist and apply.

\section{Competent court at EU level?}

Given the remaining uncertainties regarding national level remedies, interest should by directed towards the remedies potentially directly available at EU level.

\section{General Court of the European Union}

The most obvious potential remedy at EU level for an individual subject to an act of an EU body relating to criminal proceedings would be those foreseen in Articles 263(4) and 268 of the TFEU, for which, in principle, the General Court is competent under Article 256(1) TFEU. The Treaty thereby potentially opens access for individuals to EU level judicial review, both against the act under challenge as such ('primary remedy', Article 263(4)), and/or to seek damages under the EU's extra-contractual responsibility ('secondary remedy', Article 268). Given, however, the shortcomings of 'secondary remedies' from the perspective of effectiveness, as we have already seen with national courts ${ }^{22}$, and moreover the fact that the jurisprudence requires a qualified breach of EU law for damages to materialise at EU level as a consequence of a wrongful $\mathrm{act}^{23}$, this avenue will not be further pursued here.

This section concentrates instead on 'primary remedies' that go directly against the act as such at EU level, under Article 263(4) TFEU. In this regard, as is wellknown, both the text of former Art. 230(4) of the Treaty Establishing the European Community ("TEC"), and the jurisprudence which further clarified its conditions, have streamlined the availability of this remedy. ${ }^{24}$ This article will first ask how the conditions prevailing under the preceding treaty regime might have had to be interpreted, with regard to the admissibility of the claim of an individual in factual

\footnotetext{
${ }^{19}$ ECJ, Case C-6/90 and C-9/90, Francovich, 1991 ECR p. I-5357 at paras 33-4.

${ }^{20}$ ECJ, Foto Frost, supra fn 11 at para. 15.

${ }^{21}$ See Case C-221/01, Köbler v. Austria, [2003] ECR p. I-10239 at paras 121-126.

${ }^{22}$ See, supra, section I.

${ }^{23}$ See, e. g., ECJ, Case C-132/00 P, Commission v. Camar and Tico [2002] ECR I-11355 at para. 54.

${ }^{24}$ See, inter alia, Craig/De Búrca, EU law, Third Edition, Oxford 2003, pp. 487-520; Mayer, 'Individualrechtsschutz im Europäischen Verfassungsrecht', Deutsches Verwaltungsblatt 2004, p. 606 at 608; Schwarze, EU-Kommentar, Second Edition, Baden-Baden 2009, Art. 230, para. 20 et seq.
} 
circumstances as described above (a). These findings will then be built upon to discover whether the conclusions would be similar under the new Article 263(4) TFEU, given the slightly amended treaty text ${ }^{25}$, and the now binding Fundamental Right to an effective judicial remedy set out in Art. 47(1) of the Charter of Fundamental Rights (b).

\section{a) Admissibility under the preceding treaty regime}

It should be noted at the outset that acts of Europol and Eurojust were excluded from jurisdiction, since these bodies were set up under the pre-Lisbon "third pillar" and therefore the ECJ was competent only to the extent set out in Article 35 TEU, i. e. only for preliminary review if specifically accepted by the Member State concerned. Thus, from the list of possible EU acts affecting criminal proceedings, only those stemming from OLAF and other "first pillar" bodies could possibly be submitted to the Court by individuals.

As regards the conditions list of Article 230(4) TEC, there are mainly two relevant sets of criteria in this context: the first relates to the question of whether the act in hand can validly be made the object of a claim at all (i.e. whether it is a "decision"), and the second regards the additional restrictions incumbent on so-called nonprivileged plaintiffs (i.e. whether physical persons or corporations may bring this matter to the attention of the EU level jurisdiction).

\section{aa) As to whether there is a decision within the meaning of Article 230 (4) TEC}

The wording of Article 230(4) TEC in principle only allowed "decisions" to be subjected to judicial review. Whilst this term appeared to refer to the exhaustive set of legal forms in which the Community was able to act under Article 249 TEC, the jurisprudence has given it a wider meaning. The Court indeed held already in its old landmark ruling, the Plaumann case, that remedies set out in the Treaty were to be interpreted broadly ${ }^{26}$ and has confirmed this regularly, including through reference to the nature of the EU as a community of law, thereafter. ${ }^{27}$ More specifically, the Court pointed out that the real nature ${ }^{28}$ and the effects ${ }^{29}$ of an act mattered

\footnotetext{
${ }^{25}$ On these evolutions, see, inter alia, Cremer, 'Zum Rechtsschutz des Einzelnen gegen abgeleitetes Unionsrecht nach dem Vertrag von Lissabon', Die Öffentliche Verwaltung 2010, p. 58; Dougan, 'The Treaty of Lisbon 2007 : Winning minds, not hearts', Common Market Law Review 45 (2008), p. 617 at 677; Görlitz/Kubicki, 'Rechtsakte "mit schwierigem Charakter"', Europäische Zeitschrift für Wirtschaftsrecht 2011, p. 248; Hoffmann, 'Verbesserung des Rechtsschutzes aufgrund des Lissaboner Vertrages?', Asylmagazin 2010, p. 3; Kottmann, 'Plaumanns Ende: Ein Vorschlag zu Art. 264 Abs. 4 AEUV', Zeitschrift für ausländisches öffentliches Recht und Völkerrecht 2010, p. 547; Lindner, 'Der Vertrag von Lissabon zur Reform der Europäischen Union', Bayerische Verwaltungsblätter 2008, p. 421 at 432 .

${ }^{26}$ ECJ, Case 25/62, Plaumann v. Commission [1963] ECR 95: "Provisions of the Treaty regarding the right of interested parties to bring an action must not be interpreted restrictively".

${ }^{27}$ ECJ, Case C-50/00 P, Unión de pequeños agricultores v. Council [2002] ECR I-6677 at para. 44; Case C-229/05 P, PKK and KNK v. Council [2007] ECR I-439 at para. 109; Case C-432/05, Unibet [2007] ECR I-2271 at paras 37 and 44; Case C-521/06 P, Athinaïki Techniki v. Commission, [2008] ECR I-5829 at para. 45.

${ }^{28}$ ECJ, Cases 789 and 790/79, Calpak v. Commission [1980] ECR 1949 at para. 7.

${ }^{29}$ ECJ, Case C-309/89, Codorníu v. Council [1994] ECR I-1853 at para. 19.
} 
more than its form when testing whether it could be submitted for review under Article 230(4) TEC. This is perhaps best summarised in the formulation established since the $I B M$ case, whereby

(...) any measure the legal effects of which are binding on, and capable of affecting the interests of, the applicant by bringing about a distinct change in his legal position (... $)^{30}$

may be submitted to the Court under the aforementioned provision. The Court further specified this dictum by holding that a "distinct change" in the legal position of the applicant can only arise when the act is definitive, unless an intermediate measure produces independent legal effects which cannot later be challenged in proceedings brought against the definitive measure. ${ }^{31}$ As regards the required binding legal effects of the act, factual legal effects will suffice, even without intention to create legal effects. ${ }^{32}$ It is worth mentioning in this context that the case-law does not appear to view the binding legal effects of an act as a separate criterion ${ }^{33}$, but as one of the ways by which the distinct change can be brought about in the plaintiff's legal situation. ${ }^{34}$

Whilst this jurisprudence has been upheld since, ${ }^{35}$ including by the (former) ${ }^{36}$ Court of First Instance ("CFI"), its application to the facts of the Tillack case is interesting. The CFI held that an action directed against a decision by OLAF to forward information on the applicant to national criminal judicial authorities was not admissible in the absence of "distinct change" in the applicant's "legal position". ${ }^{37}$ It did so mainly by arguing that the transmission of information to national judicial authorities did not give rise to an obligation under EU law to initiate criminal proceedings. ${ }^{38}$ This may give rise to certain questions:

First, the criterion the CFI relies on denying admissibility, i.e. the distinct change of the applicant's legal position, might be considered to be actually about whether the applicant's (factual) legal situation changes distinctly, not whether (formal) legal obligations arise for the individual, as the CFI argues. One might indeed suggest that the legal situation of a person does change when a competent national authority obtains information liable to result in criminal proceedings. In particular, it would trigger a decision by prosecuting authorities whether or not to

\footnotetext{
${ }^{30}$ ECJ, Case 60/81, IBM v. Commission [1981] ECR 2639 at para. 9.

${ }^{31}$ ECJ, IBM v. Commission, supra fn 30, at para. 10; Athinaïki Techniki v. Commission, supra fn 27, at para. 54; Cases C-463/10 P and C-475/10 P, Deutsche Post and Germany v. Commission, Judgment of 13 October 2011 (not yet published in ECR, see www.curia.eu) at para. 54.

${ }^{32}$ ECJ, Case 307/81, Alusuisse v. Council [1982] ECR 3463 at para. 8: "It is therefore necessary to appraise the nature of the contested measures and in particular the legal effects which they are intended to produce or in fact produce".

${ }^{3}$ Idem.

${ }^{34}$ See CFI, Case T-193/04, Tillack v. Commission [2006] ECR II-3995 at paras 68 and 72; see also AG Bot, cases C463/10 P and C-475/10 P, Deutsche Post and Germany v. Commission, opinion of 30 June 2011, at para. 65 (www. curia.eu); but see, conversely, CFI, Case T-29/03, Comunidad Autónoma de Andalucia v. Commission [2004] ECR II2923 at para. 39 whereby lacking binding legal effect entails that there is no change of the legal situation.

35 See, e. g., CFI, Case T-309/03, Camós Grau v. Commission [2006] ECR II-1173 at para. 47; Tillack v. Commission, ibid 18 at para. 67; AG Bot, ibid at para. 65.

${ }^{36}$ Now the General Court, see Article 254 TFEU.

${ }^{37}$ CFI, Tillack v. Commission, supra fn 34, at para. 68 .

${ }^{38}$ Ibid., at paras 69-70.
} 
open a criminal case, even in Member States where the principle of opportunity applies, as well as a processing of personal data of that particular person by a public authority $^{39}$.

Secondly, the previous jurisprudence of the Court does not necessarily indicate that the applicant's legal position needs to change under EU law ${ }^{40}$, the change only had to be legal. Moreover, the legal effect in this case might even be acknowledged by EU law itself, in Article 10(2) Regulation (EC) No 1073/1999 on the powers of $\mathrm{OLAF}^{41}$, which, in its current wording ${ }^{42}$, makes this effect ("liable to result in criminal proceedings") a reason to transmit information to the national authorities in the first place.

Thirdly, even if the jurisprudence did imply that the change of the legal position had to be under EU law, the condition might be read to have been met here because the transmission of data to the national judicial authorities, if it takes place, marks the final stage of OLAF's investigation, after the final report is drawn up pursuant to Article 9 of Regulation (EC) No 1073/1999. This also emanates from the systematic structure of Articles 8-11 of the said regulation, where transmission to national judicial authorities only comes after the provision on "action taken following investigations", and no further external communication is foreseen in subsequent articles. In other words, from an EU law perspective, the transmission of the report to a national judicial authority, if it takes place, is the concrete outcome of the entire investigation and thus ends OLAF's - and the EU's - direct involvement in the case. This implies in itself a distinct change of the legal position of the plaintiff at EU level. Jurisprudence of the Court on competition law confirms this, when it views a

(...) measure definitively laying down the position of Commission or Council on the conclusion of that procedure (... $)^{43}$ (emphasis added)

as an act that may be subject to judicial review. Conversely, the jurisprudence does not seem to ask, in a similarly multi-staged process as competition law, to wait and see what national authorities would do as a matter of follow-up on the EU institutions' definitive position, before one may file a case against the last act at EU level. These same principles could be transposed to the case of transmission of OLAF reports to national authorities.

Finally, one might add that, in any event, even if it were an additional requirement, the transmission can also be seen to have binding legal effects for the Member State concerned. Here, the binding effect on Member States of the transmission of information from OLAF would arise more from the Treaty itself than from secondary legislation: Article 280(1) and (2) TEC (now Article 325(1) and (2) TFEU) provides for a special version of the general principles of effective and equivalent enforcement

\footnotetext{
${ }^{39}$ See Article 2(b) of Directive 95/46/EC on the protection of individuals with regard to the processing of personal data and on the free movement of such data, OJ L 281, 23. 11. 1995, p. 31.

${ }^{40}$ But see infra, II(1)(a)(ii) on the question of "direct concern".

41 Supra fn 8.

${ }^{42}$ See Article 1(11) of the Commission's amended proposal of 17 March 2011 for a Regulation amending Regulation (EC) No 1073/1999, COM(2011)135 final.

${ }^{43}$ ECJ, IBM v. Commission, supra fn 30, at para. 10; see also Deutsche Post and Germany v. Commission, supra fn 31, at para. 54 .
} 
of EU law by the Member States ${ }^{44}$ (and are lex specialis to Article 10 TEC mentioned by the CFI), as applied to the fight against fraud at the expense of the EU. Therefore, Member States' judiciaries - regardless of principle of legality or opportunity applying in their respective legal system - cannot simply remain idle when receiving information from OLAF, ${ }^{45}$ even though Regulation (EC) No 1073/1999 may not explicitly state this. National judicial authorities at least have an obligation stemming directly from EU law to screen the information provided by OLAF and check whether there is an initial level of suspicion of a criminal offence as characterised under national law, with a view to effectively enforcing EU law. ${ }^{46}$ This obligation of due diligence is recognised by the CFI itself - nonetheless, and without considering Article 280 TEC in this context, the CFI draws the conclusion that Article 10(2) of Regulation (EC) No 1073/1999 does not trigger an obligation to take "specific" measures. ${ }^{47}$ One might find it worth discussing whether this restrictive reading of the Regulation, which denies any obligation of Member States arising from Article 10(2) of the Regulation, is in line with the obligation to act set out in Article 280 TEC, which would prevail in the case of conflict, ${ }^{48}$ and thus should guide the interpretation of Article 10(2). Moreover, the requirement of an obligation to take "specific" measures arising from the act subject to judicial review was not apparent in earlier jurisprudence of the Court on Article 230(4) TEC, ${ }^{49}$ and it is a difficult criterion to apply: what, one may ask for instance, makes Article 280(1) and (2) TEC insufficiently specific? Even if one were to regard the reference to the lack of obligation to take "specific" measures as a case-specific approach to Article 10(2) of Regulation (EC) No 1073/1999, without potential for generalisation, it should be noted that in the recent Deutsche Post case the Court of Justice has found the General Court too demanding as regards the question of an EU measure's binding legal effects. ${ }^{50}$

\section{bb) Standing of a non-privileged plaintiff regarding a measure not addressed to him/her}

The question remains, however, whether acts such as those described above could have been brought to the Court by a person concerned by the (ongoing or later) criminal proceedings, even though the act in question was not addressed to the plaintiff, but to the national authority investigating or prosecuting the former. Hence, this is about third-party access to judicial review, and the wording of Article

\footnotetext{
${ }^{44}$ ECJ, Case 68/88, Commission v. Hellenic Republic ('Greek corn') [1989] ECR 2965 at para. 24.

${ }^{45}$ See also Wakefield, 'Case T-193/04, Hans-Martin Tillack v. Commission, judgment of the Court of First Instance (Fourth Chamber) of 4 October 2006, [2006] ECR II-3995', Common Market Law Review 2008, p. 199 at 204.

${ }^{46}$ See for statistics on the outcome of such screening the Commission Staff Working Document accompanying the Communication on the protection of EU financial interests by criminal law and by administrative investigations, SEC (2011)621 final, tables 2.2(a) and 2.2(b).

${ }^{47}$ CFI, Tillack v. Commission, supra fn 34, at para. 72.

${ }^{48}$ See ECJ, Case 1/67, Ciechelski v. Caisse régionale de sécurité sociale du Centre [1967] ECR 181 at 188.

${ }^{49}$ Rather it is taken from the wording of the order of the President of the Court of Justice in the preceding appeal against the CFI's denial of the application for interim relief, Case C-521/04 P (R), Tillack v. Commission supra fn 34, at para. 33 .

${ }^{50}$ Supra fn 31, at para. 45.
} 
230(4) TEC, as well as the elaborate set of jurisprudence developed in this context. More specifically, the criteria of "direct and individual concern" to the plaintiff, as foreseen in Article 230(4) TEC, come into play at this stage.

To speak plainly, the question of direct concern is not a straightforward one in these cases. Whilst the relevant criteria have been settled by constant jurisprudence, ${ }^{51}$ their application to the facts at hand here is neither tested - because the CFI denied comparable submissions already at the earlier stage of a "challengeable act" ${ }^{52}$ - nor obvious, as the jurisprudence developed around rather different factual circumstances. The core definition of direct concern applied by the Court in the cases it was called upon to decide is as follows:

"...requires the contested Community measure to affect directly the legal situation of the individual and leave no discretion to its addressees, who are entrusted with the task of implementing it, such implementation being purely automatic and resulting from Community rules without the application of other intermediate rules. "53

One might be tempted to argue, similarly as the CFI in Tillack ${ }^{54}$, that the national authorities remain free to engage in a criminal proceeding against the plaintiff, and that this discretion prevents "direct concern" within the meaning of Article 230(4) TEC from being established. Bearing in mind, however, that the above case-law has evolved mostly ${ }^{55}$ in state aid, subsidy and competition cases, where the Commission addressed the (Member) State as such with a view to correcting an alleged breach of EU law by a Member State, which may or may not have benefited an individual, one could also consider reading this jurisprudence mutatis mutandis in the present context. Indeed, here, as opposed to the factual setting dominating the case-law, the EU bodies directly address a judicial authority in a Member State with regard to an individual's acts. Whilst the acts in question may not trigger an obligation to open a criminal case against that person, they do carry an EU law obligation to exercise due diligence at least in pre-investigative screening of the case. ${ }^{56}$ This due diligence

\footnotetext{
${ }^{51}$ See, e. g., ECJ, Joined Cases 41/70 to 44/70 International Fruit Company and Others v. Commission [1971] ECR 411 at paras 23 to 29; Case 92/78 Simmenthal v. Commission [1979] ECR 777 at paras 25 and 26; Case 113/77 NTN Toyo Bearing Company and Others v. Council [1979] ECR 1185 at paras 11 and 12; Case 118/77 ISO v. Council [1979] ECR 1277 at para. 26; Case 119/77 Nippon Seiko and Others v. Council and Commission [1979] ECR 1303 at para. 14; Case 120/77 Koyo Seiko and Others v. Council and Commission [1979] ECR 1337 at para. 25; Case 121/77 Nachi Fujikoshi and Others v. Council [1979] ECR 1363 at para. 11; Joined Cases 87/77, 130/77, 22/83, 9/84 and 10/84 Salerno and Others v. Commission and Council [1985] ECR 2523 at para. 31; Case 333/85 Mannesmann-Röhrenwerke and Benteler v. Council [1987] ECR 1381 at para. 14; Case 55/86 Arposol v. Council [1988] ECR 13 at paras 11 to 13; Case 207/86 Apesco v. Commission [1988] ECR 2151 at para. 12; Case C-152/88 Sofrimport v. Commission [1990] ECR I2477 at para. 9; Case C-386/96 P, Dreyfus v. Commission [1998] ECR I-2309 at para. 43; Case C-404/96 P Glencore Grain v. Commission [1998] ECR I-2435 at para. 41; Case C-486/01 P, Front national v. Parliament [2004] ECR I-6289 at para. 34; Case C-417/04 P, Regione Siciliana v. Commission [2006] ECR I-3881 at para. 28; Case C-125/06 P, Commission v. Infront WM [2008] ECR I-1451 at para. 47; Deutsche Post and Germany v. Commission, supra fn 31, para. 66.

52 Tillack $v$. Commission, see supra fn 34, and section III(1)(a)(i).

${ }^{53}$ Commission v. Infront $W M$, supra fn 51, at para. 47.

${ }^{54}$ CFI, Tillack v. Commission, supra fn 34 , at para. 70.

55 The exception would be the case Front national v. Parliament, supra fn 51 , but its facts (case submitted by national party structure to review a decision by the Parliament affecting individual Members of Parliament) are about political interest of a party vs legal interest of individuals, and thus not comparable to those at hand here.

${ }^{56}$ See supra, section II(1)(a)(i).
} 
obligation is, moreover, intrinsically directed against a particular individual named, or identifiably described, in the EU act. All of these aspects taken together might be viewed as allowing the present factual circumstances to be distinguished from those to which most of the settled case-law applies. In particular, the "task of implementing" a decision cannot be a relevant aspect here.

The spirit of the case-law nonetheless offers a useful line of thinking to apply the criterion of "direct concern" of the Treaty, whereby the individual must be exposed to a legal process triggered by the EU act as such (thus the Court's criterion "affect directly the legal situation" ${ }^{57}$ ), and without there being any need or possibility for the addressee to do anything about it (thus the criterion "purely automatic" ${ }^{58}$ ). Both of these more general criteria, however, are met here, since the plaintiff cannot elude the pre-screening which will have to be undertaken, as a matter of EU law, by the judicial authority of the Member State in question.

As regards the acts' individual concern to the plaintiff, the Plaumann ${ }^{59}$ and, more recently, the $U P A$ case $^{60}$ offer relevant insights. The jurisprudence aims at excluding from judicial review cases brought by individuals against normative texts, without there being:

"...certain attributes peculiar to [these individuals], or (...) a factual situation which differentiates them from all other persons and distinguishes them individually in the same way as the addressee ${ }^{61}$."

In the instant cases, there is little doubt that a file concerning potential criminal investigations of a certain individual, and acts involving transmission or operational advice on such cases, are of particular individual concern to the potential suspect, accused or defendant in the national proceedings.

One might wonder, however, whether such acts are also of individual concern to the (alleged) victim, and/or a whistleblower. This is a much less convincing notion. In fact, however much one might legitimately seek to improve the victims' rights and their ease to obtain redress in criminal proceedings ${ }^{62}$, the process remains, at its core, one of prosecution on behalf of society against the suspect, defendant or accused. Criminal proceedings are conducted in the public interest, not the private. $^{63}$ This is because criminal liability, as opposed to civil liability, is incurred for conduct regarded by the legislator as so egregious that, even in cases of a single individual being the victim, the State should intervene by means of a special process which not only carries potentially particularly harsh sanctions, but also a stigma of

\footnotetext{
${ }^{57}$ Commission v. Infront WM, supra fn 51, at para. 47.

${ }^{58}$ Idem.

${ }^{59}$ Supra fn 26, at penultimate para. of part I.

${ }^{60}$ Supra fn 27, at para. 36.

61 Idem.

${ }^{62}$ See Commission proposal of 18 May 2011 for a Directive establishing minimum standards on the rights, support and protection of victims of crime, $\operatorname{COM}(2011) 275$ final.

${ }_{63}$ The so-called "private accusation" (Privatklage) proceedings available in certain cases in Germany (see $\$ 374$ Strafprozessordnung) are no exception to this rule, as the private victim is pursuing the State's right to obtain criminal sanction against the perpetrator, in functional replacement of the public prosecutor who is otherwise procedurally competent for doing so, see e. g. Meyer-Goßner, Strafprozessordnung, $49^{\text {th }}$ edition, Munich 2006, $\S 374$ at para. 5.
} 
wrongdoing for the individual convicted at the end of it. ${ }^{64}$ For our purposes here, this means, however, that a victim, and even more so a mere witness or whistleblower without victim status, cannot be regarded as individually concerned by an EU act affecting criminal proceedings potentially to be conducted on behalf of society against someone else. Or, to put it in the words of the Court, they are not distinguished individually in the same way as (the proceedings) addressee.

\section{b) Admissibility under the new Article 263(4) TFEU}

Under the new Treaty framework, the former "third pillar" bodies are no longer excluded as a matter of principle from the ECJ's jurisdiction. Under Article 10(1) of Protocol No 36 on Transitional Provisions annexed to the TEU and TFEU, the Court will, however, only acquire its jurisdiction with regard to them five years after entry into force of the Treaty of Lisbon, i. e. on 1 December 2014, unless an amendment to these acts results in competence of the Court prior to this point (Article 10(2) of Protocol No 36).

To the extent the ECJ has jurisdiction, certain new elements might need to be taken into account when it comes to considering the same questions of admissibility under Article 263(4) TFEU, as this provision is slightly - but significantly redrafted, and placed into a new treaty context.

\section{aa) Broader wording of the new Treaty?}

The first such element of change stems from the wording of Article 263(4) TFEU itself. Whilst Article 230(4) TEC related to a "decision" ("décision"/"Entscheidungen") before, though it was interpreted by the Court non-formalistically ${ }^{65}$, the treaty language itself now refers to an "act" ("actes"/"Handlungen"). Even though this modification may not have been intended to entail revolutionary modifications of the judicial review system, it is unconvincing to regard it as purely one of labelling. ${ }^{66}$ If it had been a redactional change alone, the move away from "decision" to "act" in Article 263(4) TFEU would also have had to be mirrored in the changes to exArticle 249 TEC, now Article 288 TFEU, which provides for the list of legal forms in which the EU may take action and which already previously contained the "decision". Yet none of the language versions known to this author of Article 288 TFEU now contains the equivalent of the term "act" as one of the forms in which the EU may become legally active. Rather, "act" as a stand-alone term ${ }^{67}$ clearly remains a peculiarity of Article 263(4) TFEU. The conclusion can only be that securing a broad scope of Court review powers was intended by the drafters.

\footnotetext{
${ }^{64}$ For a recent confirmation of the legislator's adherence to this understanding, see Recital no 3 of Directive 2008/ 99/EC of the European Parliament and the Council of 19 November 2008 on the protection of the environment through criminal law, OJ L 328, 6. 12. 2008, p. 28.

65 Supra section II(1)(a)(i).

${ }^{66}$ See, e. g., Cremer in: Calliess/Ruffert, EUV - AEUV, $4^{\text {th }}$ edition, Munich 2011, Art. 263 at para. 31-2.

${ }^{67}$ There are, however, references to legal acts, legislative acts (Article 289(3) TFEU), delegated acts (Article 290(3) TFEU) or implementing acts (Article 291(4) TFEU).
} 
This in not necessarily to be viewed as a change to, but rather as a codification of earlier jurisprudence ${ }^{68}$. Indeed the Court has used the term "act" ${ }^{69}$ even before the Lisbon Treaty entered into force, albeit not in as broad a sense as to cover also EU measures or activities with a merely factual (as opposed to legal) effect ("Realakt"). From this perspective of continuity between jurisprudence and new treaty language, there is no indication that the latter acts should now be covered. ${ }^{70}$

In a nutshell, the new language confirms individuals' existing rights to judicial review for measures which modify the plaintiff's legal situation, regardless of whether such legal effects were intended, and irrespective of whether they stem from EU law as such or its implementation in the Member States. All of these criteria are met in the factual circumstances analysed by this article (e.g. transmission of information to national prosecutors) ${ }^{71}$.

\section{bb) Broader interpretation in the light of the EU Charter of Fundamen- tal Rights?}

The second element of change is the binding force of the Charter, which according to Article 6(1) TEU now has the same legal value as the Treaties.

Again, the question arises whether the Treaty only incorporated into primary law pre-existing jurisprudence or whether it implies real changes. The Court of course has had a long-standing tradition of taking into account fundamental rights as a matter of constitutional traditions common to the Member States ${ }^{72}$, as crystallised in particular in the European Convention on Human Rights and Fundamental Freedoms ("ECHR") ${ }^{73}$. Interpretation of the Treaties in the light of fundamental rights had thus become a standard method even before the Lisbon Treaty. ${ }^{74}$ Moreover, one may argue on the basis of the drafting history that Article 47(1) of the Charter does not seek to "change" the existing appeals system of the Treaties. ${ }^{75}$

However, the drafters also contended that the principle of effective judicial remedies is to be implemented according to the procedures laid down in the Treaties. $^{76}$ Since the term implementation does imply a certain impact, it is also possible to interpret the drafters as having at least envisaged that the admissibility criteria set out in the Treaty would henceforth be interpreted in the light of Article

\footnotetext{
${ }^{68}$ See CONV 636/03, Final Report of the discussion circle on the Court of Justice, 25 March 2003, at para. 23, http://register.consilium.europa.eu/pdf/en/03/cv00/cv00636.en03.pdf.

${ }^{69}$ E.g. ECJ, Union de pequeños agricultores, supra fn 27 at para. 40; Athinaïki Techniki v. Commission, supra fn 27 at para. 45 .

${ }^{70}$ A different interpretation is advocated by Mayer, "Wer soll Hüter der europäischen Verfassung sein?", Archiv. des öffentlichen Rechts 2004, p. 411 at 427.

${ }^{71}$ Supra section III(1)(a)(aa).

72 ECJ, Case 29/69, Stauder v. Ulm [1970] ECR 419 at para. 7; Case 11/70 Internationale Handelsgesellschaft [1970] ECR 1125 at para. 2.

${ }^{73}$ See, e. g., ECJ, Case 222/84, Johnson v. Royal Ulster Constabulary [1986] ECR 1651 at para. 18; Case C-12/00, Schmidberger v. Austria [2003] ECR at para. 72.

${ }^{74}$ See, e. g., Schmidberger $v$. Austria, ibid., at paras 77-81.

${ }^{75}$ See the Explanations of the Convention's Praesidium on the Charter of Fundamental Rights, 11 October 2000, CONVENT 49, p. 41, http://www.europarl.europa.eu/charter/convent49_en.htm.

${ }^{76}$ Idem.
} 
47(1) of the Charter, rather than lacking any effect whatsoever. Moreover, the view that Article 47(1) of the Charter changes nothing does not sufficiently take into account that the appeals system may only reasonably be brought into line with a right to judicial review as the one enshrined in the Charter, if judicial control of the EU act at hand may be triggered by the plaintiff himself. This is not the case concerning the "fall-back remedy" of preliminary rulings to the ECJ, which the Court mentioned under the past Treaty regime as that which allegedly completes the appeals system ${ }^{77}$, since here the plaintiff depends on the national court for the question to be brought to the ECJ's attention ${ }^{78}$.

As a result, and for our purposes, this means in particular that the right to an effective judicial remedy provided for in Article 47(1) of the Charter has to be complied with by secondary legislation ${ }^{79}$, but also, and more importantly for this article, that Article 263(4) TFEU must be interpreted in light of it to avoid intraTreaty collisions $^{80}$. More concretely, only an interpretation of Article 263(4) TFEU, in the light of Article 47 of the Charter, which fills the gaps previously left to preliminary rulings -due to narrow interpretation of Article 230(4) TEC- can suffice the new Treaty system.

This means that it might not be possible for a plaintiff to be relegated to the theoretical possibility of implicit control of EU acts in proceedings against national follow-up measures, by means of a potential preliminary ruling, depending on the choice or interpretation of the national judge. This seems all the more the case when it comes to national criminal proceedings: The particular safeguards contained in Articles 48-50 of the Charter regarding criminal proceedings bear witness that this is indeed a field to be treated with particular sensitivity concerning fundamental rights, and that the relative weight of Art. 47(1) is thus even greater in such circumstances. Against this background, the very fact that criminal proceedings are being considered at all by a competent authority, on the basis of information or subsequent to other forms of EU involvement, is already such an intense interference with fundamental rights that Article 47(1) of the Charter must be read to require a previous judicial check on the EU act which triggered or otherwise allowed such a process to continue, at the sole discretion of the person concerned as a potential suspect, the accused or defendant in (later) criminal proceedings. One cannot expect the plaintiff, in such circumstances, to wait and see what the outcome of the criminal proceedings might be, only then to argue before the national judge that the EU act was flawed and a question should be referred to the ECJ for preliminary ruling. Such an approach would hardly be satisfactory as a matter of the right to an effective remedy. Two additional reasons add to the argument in favour of admissibility in the particular circumstances which are of interest to us here:

\footnotetext{
${ }^{77}$ E.g. Case C-50/00 P, Union de pequeños agricultores, supra fn 27, at para. 40.

${ }_{78}$ See Wakefield, Common Market Law Review 2008, supra fn 45, at p. 208.

${ }^{79}$ Kingreen in Calliess/Ruffert, supra fn 66, Art. 6 EUV at para. 12.

${ }^{80}$ See, mutatis mutandis, ECJ, Case 22/70, AETR [1971] ECR 263 at para. 15; Case 149/77, Defrenne v. Sabena (III) [1978] ECR 1365 at para. 15; see also Leible/Domröse in: Riesenhuber (ed.), Europäische Methodenlehre, Berlin $2006, \S 9$ at para. $64-5$.
} 
First, the prosecutorial phase of criminal proceedings usually cannot be brought to the attention of a national judge unless and until the prosecutor decides to bring it to court himself/ herself - if one considers that the prosecutorial phase was caused by an EU act here, this calls all the more for EU judicial review of that EU act, in order to avoid the "dragging on" during the proceedings' entire prosecutorial phase of an EU-caused interference with fundamental rights without judicial review.

Secondly, the national laws of the Member States do not always bar the use of illegally acquired evidence ${ }^{81}$, and even less of evidence lawfully acquired on the basis of a suspicion triggered by illegally acquired evidence (as opposed to the "fruit of the poisonous tree" doctrine in the United States) ${ }^{82}$. In such circumstances, the alleged illegality of the EU act would not even be of relevance for the decision of the national judge, and thus, even for a national court whose judgment is not subject to appeal, there would be no obligation under the TFEU to submit the case for preliminary ruling to the ECJ - so that if the national court submitted it nonetheless, the question would be inadmissible under Article 267(2) and (3) TFEU. Such systematic aspects could moreover be viewed to prevail, as a matter of interpretative methodology, over the historical intent of the drafters, had it been different. ${ }^{83}$

\section{Court of Justice of the European Union}

A further avenue to be considered for judicial review to take place would be proceedings directly before the Court of Justice, either by means of a Commission submission or by the person concerned himself/ herself.

\section{a) Proceedings brought to the Court of Justice by the Commission}

One could consider the possibility of ex parte proceedings of the Commission against the body in question as a matter of infringement proceedings.

However, as regards OLAF acts, since OLAF is organisationally a part of the Commission and thus of the same institution, the Commission cannot bring a claim to court, even concerning conduct in the investigative field where the Director- of OLAF is independent from otherwise applicable hierarchies (Article 12(3) of Regulation (EC) No 1073/1999). This view is bolstered by an a contrario reading of the said provision, whereby the Director-General of OLAF is entitled to present a claim to the Court for interference with his independence, but no reverse process is foreseen. This a contrario seems more compelling here than an analogy resulting in the opposite outcome, because the said provision is an exception to the rule whereby a person may not bring court action against (a functional branch of) itself. This state-of-affairs is not without functional justification, as the very need for investigative independence legitimately foreseen in Regulation (EC) No 1073/1999 could

\footnotetext{
${ }^{81}$ For France, see Cour de cassation, crim 23/7/92, Bull crim №274 P 744; for Germany, see Bundesverfassungsgericht, Neue Juristische Wochenschrift 2000, p. 3557; Meyer-Goßner, supra fn 63, introduction at para. 55.

${ }^{82}$ For Germany, see Bundesgerichtshof, BGHSt 27, p. 355 at 357; BGHSt 29, p. 244 at 249; Meyer-Goßner, supra fn 63, introduction at para. 57.

${ }^{83}$ See Pechstein/Drechsler in: Riesenhuber (ed.), supra fn $80, \S 8$ at para. 32.
} 
be circumvented or undue pressure exerted in matters falling outside the scope of Commission hierarchical powers. Given Article 47(1) of the Charter, this conclusion also likely entails that the right of the individual to obtain judicial review is stronger under the current Treaty ${ }^{84}$.

As regards other bodies, offices and agencies of the Union, their acts must now be subject to review, including by the Commission, under Article 263(1) second sentence TFEU. However, the Commission enjoys discretion as to whether or not it should bring infringement proceedings ${ }^{85}$, and it cannot therefore be regarded as an effective judicial remedy within the meaning of Article 47(1) of the Charter for the person concerned.

\section{b) Proceedings brought to the Court of Justice by the person con- cerned}

Another approach would be to deem the normative effect of Article 47(1) of the Charter insufficiently reflected in the wording of Articles 258 and 263 TFEU, thus requiring the interpretation of the entire set of Treaty provisions on access to court as implying an extraordinary subsidiary review mechanism. The Court on at least one occasion did accept indeed to go beyond the wording of the provisions on admissibility as contained in the provisions of the Treaty taken individually, and found that a "request for judicial cooperation" put forward by a national, with the aim of ordering the Commission to produce documents, was admissible. ${ }^{86}$

However the circumstances of that case were different, as it related to a request from a national court, thus in line with the logic of preliminary rulings, and not lending itself to generalisation. Nothing similar can be drawn from Article 47(1) of the Charter, which "only" has the same normative rank as the Treaties and thus cannot entirely upset the balance of the review procedures provided in Articles 258 et seq. TFEU. ${ }^{87}$

\section{Review by the European Court of Human Rights?}

Despite an obligation to accede provided in Article 6(2) TEU as amended by the Treaty of Lisbon, and the corresponding possibility foreseen under Article 59(2) of the (European) Convention for the Protection of Human Rights and Fundamental Freedoms (the "ECHR") ${ }^{88}$ as amended by Protocol no 14 thereto $^{89}$, the EU is not yet a member of the ECHR. ${ }^{90}$ The European Court of Human Rights (the

\footnotetext{
${ }^{84}$ See supra, section III(1)(b).

${ }^{85}$ See, e. g., Geiger, EUV/EGV, $3^{\text {rd }}$ edition, Munich 2000, Art. 211 at para. 8.

${ }^{86}$ Case C-2/88 IMM, J.J. Zwartveld and others, [1990] ECR I-3365.

${ }^{87}$ Explanations of the Convention's Praesidium on the Charter of Fundamental Rights, supra fn 75.

88 Opened for signature in Rome on 4 November 1950, ETS no 005, entered into force on 3 September 1953.

${ }^{89}$ Protocol amending the control system of the Convention, opened for signature in Strasbourg on 13 May 2004, CETS no 194, entered into force on 1 June 2010.

${ }^{90}$ For background information from the Council of Europe on the ongoing process, see http://www.coe.int/ lportal/web/coe-portal/what-we-do/human-rights/eu-accession-to-the-convention, and the speech of Vice-Presi-
} 
"ECtHR") is nonetheless a relevant actor for our purposes, both because of the indirect impact of its jurisprudence on the ECJ, and because of the (at least theoretical) possibility to bring an action concerning an EU act to Strasbourg as well, by means of a case directed against an EU Member State for its responsibility for the consequences on ECHR rights of the EU Treaties it acceded to ${ }^{91}$.

The general stance of the ECtHR is that the right to judicial review shall be given a broad interpretation, and it includes, in particular, the necessary coverage of preparatory acts of criminal proceedings, without depending on whether those (already) carry the label "criminal proceeding" or represent a formal "charge" under the applicable law. ${ }^{92}$ The ECtHR also emphasises in the context of access to court that the Convention does not intend to guarantee rights which are theoretical or illusory, but rights that are practical and effective. ${ }^{93}$

In the light of this requirement of effectiveness, the ECtHR is understandably sensitive to the interplay of administrative and criminal proceedings, in particular if information gained in the former is used as evidence in the latter, despite the lower procedural safeguards applying to the administrative proceedings. ${ }^{94}$ The ECtHR also disapproves of the unavailability of an effective judicial remedy as a consequence of combining, upon the authorities' initiative, main and ancillary proceedings, if a settlement reached in one of the two makes it impossible to bring a complaint concerning the other. ${ }^{95}$ When viewed together, this case law might seem to indicate that the unavailability of a separate judicial remedy against an administrative contribution to a later criminal proceeding must be considered problematic from an ECHR perspective, if and to the extent this previous conduct by another authority could otherwise not be effectively checked in the main proceedings any more.

\section{Conclusion}

Given the binding force of the EU Charter of Fundamental Rights which enshrines the right to effective judicial review by reference to ECtHR jurisprudence $^{96}$, and the expected accession of the EU to the ECHR, it will be rewarding to follow the jurisprudence of the ECJ and ECtHR and see whether and how they might evolve as regards judicial review of acts of the EU affecting criminal proceedings.

\footnotetext{
dent Reding to the European Parliament's Constitutional Affairs committee of 18 March 2010, http://ec.europa.eu/ commission_2010-2014/reding/pdf/speeches/speech_20100318_1_en.pdf.

${ }^{91}$ See Matthews v. United Kingdom [GC], no 24833/94, ECHR 1999-I at para. 33; MSS v. Belgium and Greece [GC], no 30696/09, http://hudoc.echr.coe.int, at para. 338; but also note the presumption of ECHR compliance Bosphorus Hava Yollan Turizm v. Ticaret Anonim Sirketi v. Ireland, no 45036/98, ECHR 2005-VI at paras 159-165.

92 Öztürk v. Germany, no 8544/79, Series A no 73 at paras 49-50 and para. 55; see also Zolotukhin v. Russia [GC], no 14939/03, http://hudoc.echr.coe.int, at para. 81, for a similar reasoning on Article 4 of Protocol no 7.

${ }^{93}$ E.g. Airey v. Ireland, no 6289/73, Series A no 32 at para. 24.

94 Saunders v. United Kingdom [GC], no 19187/91, ECHR 1996-VI at para. 75.

${ }_{95}$ Deweer v. Belgium, no 6903/75, Series A no 35 at para. 49.

${ }^{96}$ Explanations of the Convention's Praesidium on the Charter of Fundamental Rights, supra fn 75.
} 